The 16th Economic International Conference New Challenges and Opportunities for the Economy 4.0, May 7-8th, 2020, Suceava, Romania

\title{
Integrating Risk Management into Decision Making
}

\author{
Florin BOGHEAN
}

$\underline{\text { https://doi.org/10.18662/lumproc/ncoe4.0.2020/10 }}$

How to cite: Boghean, F. (2020). Integrating Risk Management into Decision Making. In C. Nastase (vol. ed.), Lumen Proceedings: Vol. 13. 16th Economic International Conference NCOE 4.02020 (pp. 105-114). Iasi, Romania: LUMEN Publishing House.

https://doi.org/10.18662/lumproc/ncoe4.0.2020/10 


\title{
Integrating Risk Management into Decision Making
}

\author{
Florin BOGHEAN ${ }^{1}$
}

\begin{abstract}
The main forms of risk are can be grouped in eight categories: economical risks, financial risks, commercial risks, manufacturing risks, political risks, social risks, juridical risks, natural risks. Through its nature the decision is referring to the future, mainly being provisional. In any decisional process developed at the company level, there are involved in the same time some economical, techniques, juridical, human and managerial variables. As a consequence of the decision (generally) and of managerial decision (particularly), because of its complexity and its contextual deter in its growth there are associated many risks.
\end{abstract}

Keywords: risk management; corporate governance; decision-making process.

${ }^{1}$ Stefan cel Mare University, Suceava, Romania, florinboghean@,usm.ro 


\section{Theoretical background}

Why is it important for a company's risks to be managed? Risk management is one of the key concepts for long-term success in financial markets. You could be the most talented trader in the world, with a natural sense of identifying investment opportunities but you can lose your money in one fell swoop without proper risk management. No matter how good or experienced you are, you can make losses. In general, the notion of risk has negative connotations [1]. People think about the possibility of losing something or about certain negative things that can happen. However, in the economic conception it is accepted that the risks can materialize in favor of the entity in an advantageous way. General risk (purely inherent and environmental risk). derives from aspects related to: management, accounting function, nature of business and the auditor's previous experiences with the client. Specific risk derives from aspects related to the auditor's previous experience and from the current understanding of each area of the audit [2].

At present, any economic decision is taken under conditions of uncertainty, in the sense that all identified events that may occur and adversely affect the achievement of objectives must be taken into account [3]. Under certain conditions, all events can be known (in terms of their appearance) from the beginning, with no risk. In reality, risk is an intrinsic factor of business decisions. He cannot be ignorant, and can never be reduced to zero. In general, the profitability of a project, an investment or a decision must be higher the higher the risks that hover over the results. Investors or decision makers expect to be remunerated in addition for the additional risk assumed. Thus, when choosing between two projects with identical results and different risks, any rational investor would choose the one with lower risks [4]. Risk identification is the first step in the risk assessment process. The purpose of this process is to identify events that pose a risk as early as possible, thus reducing or eliminating surprises. As a result of identifying the risk, risk analysts may develop a sense of the sources of risk (or opportunities) that will affect the company's projects and operations. Then, they analyse, from a qualitative and quantitative point of view, the impact of risky events, which is the second step in the risk assessment process.

On the other hand, the entity may face both risks and uncertainties. Uncertainty refers to the impossibility of identifying a particular event that may occur or, if it is identified, to the impossibility of estimating its probability of occurrence. By contrast, risk allows the identification of the 
event and the probability of occurrence (even if only estimated), being rather the impossibility of knowing exactly whether an event will happen or not.

\section{Research methodology}

The specialized literature defines the research methodology and the construction of the text of a paper as a "way" to be followed in the research activity to achieve the objectives, namely for information and training. To reach the goals of this research, I relied on a qualitative approach using a general-to-private approach [5]. Regarding the human and social sciences, this research is based on the non-participant observation, more precisely the inductive research method is applied, on the document analysis and on the comparison techniques [6].

\section{Managers perceptions of risk management}

Risk management practices have long been debated in the academic and practitioner literatures [7]. The required benefits have gone beyond simply reducing risk by extending to company-wide performance improvements [8], [9], [10].

Once the risk events have been identified, their probability and impact must be determined. Is it likely to occur? If so, will they cause financial harm to the organization or cause delays in product delivery, or will they result in poor quality deliverables?

Specialized literature specifies different methods by which risk identification exercises may be performed [7]:

- checklists;

- brainstorming sessions;

- registers or lists of problems;

- behavioural patterns;

- schematization techniques;

- performing a logical scheme of the project and some process models;

- regular meetings.

In the case of business, the entity must try to turn uncertainties into risks [11], in the sense of seeking to identify events that may affect the achievement of its objectives, as well as the probability of occurrence and the possible impact on them. This transformation is essential for those 
responsible to be able to make informed decisions. The greater the uncertainty, the more uncertain the result and the greater the exposure to loss. [1]

Table no.1. Definitions of types of risk in the specialized literature of operations management

\begin{tabular}{|c|c|c|}
\hline References & Risk attributes & Definition \\
\hline Zsidisin (2003) & $\begin{array}{l}\text { Vendor risk arises from } \\
\text { vendor failures and market } \\
\text { failures. } \\
\text { Vendor risk is associated } \\
\text { with the inability to meet } \\
\text { customer requirements or } \\
\text { threats to the customer's } \\
\text { life and safety. }\end{array}$ & $\begin{array}{l}\text { "Vendor risk is defined as the probability } \\
\text { of an incident associated with vendor } \\
\text { failures to individual suppliers or market } \\
\text { failures, which leads to the inability of the } \\
\text { acquiring firm to meet customer demand or } \\
\text { poses threats to customer life and safety." } \\
{[12]}\end{array}$ \\
\hline $\begin{array}{l}\text { Talluri, } \\
\text { Narasimhan, } \\
\text { Nair (2006) }\end{array}$ & $\begin{array}{l}\text { Symmetrical about losses } \\
\text { and gains. } \\
\text { Non-linear effect of } \\
\text { deviations from average } \\
\text { results. } \\
\text { Unlimited negative or } \\
\text { positive possibilities. } \\
\text { The risks are independent } \\
\text { one from the other. }\end{array}$ & $\begin{array}{l}\text { "Gaussian distribution of attributes of } \\
\text { possible performance variables". [13] }\end{array}$ \\
\hline $\begin{array}{l}\text { Knemeyer, } \\
\text { Zinn, Eroglu } \\
(2009)\end{array}$ & $\begin{array}{l}\text { Out-of-company } \\
\text { interruptions that may } \\
\text { continue to have an } \\
\text { impact on the company's } \\
\text { business. }\end{array}$ & $\begin{array}{l}\text { "Supply chain risk is the probability of an } \\
\text { event multiplied by the impact on the } \\
\text { business". [14] }\end{array}$ \\
\hline $\begin{array}{l}\text { Gray, } \quad \text { Roth, } \\
\text { Leiblein (2011) }\end{array}$ & $\begin{array}{l}\text { Asymmetric on losses and } \\
\text { gains. } \\
\text { It may be related to a } \\
\text { specific reason (for } \\
\text { example, }\end{array}$ & $\begin{array}{l}\text { "Quality risk is the tendency of a } \\
\text { manufacturing style to disregard good } \\
\text { manufacturing practices, which in theory } \\
\text { increase the likelihood of product quality } \\
\text { defects." [15] }\end{array}$ \\
\hline
\end{tabular}




\begin{tabular}{|c|c|c|}
\hline $\begin{array}{l}\text { Zwikael and } \\
\text { Sadeh (2007) }\end{array}$ & $\begin{array}{l}\text { The risk is perceptual } \\
\text { The risk can be felt at the } \\
\text { beginning of a project } \\
\text { without the need for a } \\
\text { formal assessment. }\end{array}$ & $\begin{array}{l}\text { "Uncertainty of a managed project that can } \\
\text { be properly rated on a risk scale of } 1 \text { to } \\
10 . " \text { [16] }\end{array}$ \\
\hline
\end{tabular}

Source: author's own processing

The Long-Term Capital Management Hedge Fund included two Nobel laureates, who, after accumulating a large amount of capital, continued to lose more than $\$ 4$ billion over several months following the 1998 financial crisis in Russia [17]. The fund requires the intervention of the Federal Reserve to get out of its investments. Excessive and abusive use of such sophisticated methods of analysis has also been blamed for the 2008 global financial crisis and for financial crisis in general [18]. In fact, some hedge fund managers have made large sums of money by exploiting defects in such analyses [19]. In comments on the 2008 financial crisis, Lewis (2010) explains that the nationally unrelated housing price hypothesis has allowed diversified combinations of low-quality individual mortgages to be sold at a higher quality as a result of their orders payment priority and diversification between several mortgages. By making the opposite investments, several managers were able to take advantage of the crisis [20].

\section{The risk management process}

The risk management activity is an important concern for the management of the entity. It is also taken into account that the risk cannot and should not be completely eliminated from the business environment. Its management is fundamental to try to reduce the negative effects involved in its manifestation. Because complete risk avoidance is not possible, the entity's management must focus on avoiding uncontrollable and incomprehensible risk categories, as well as on ensuring the monitoring and use of risks that contribute to increased performance.

Risk management is a dynamic process of identification, internal audit and ongoing monitoring of risks with a positive or negative impact on activity and results. Risk management is a process that is carried out by the Board of Trustees or the Board of Directors, together with a number of people from the different structures of the entity whose object is: 
- establishing the strategy and identifying the elements that may affect the entity, its activity and results;

- the management of future risks within the limits of the entity's vulnerability to risk, in order to provide a satisfactory level of assurance regarding the achievement of the entity's objectives;

- it is generalized in the entire entity, at each level, structure and form of organization-functioning, the internal audit offering a general and complete perspective on the risks;

- identification and internal audit of events, transactions, operations that may affect the achievement of the entity's functional objectives and expected results, monitoring of identified risks within the limits of risk appetite;

- offering a satisfactory insurance at management level;

- directing all processes towards achieving the objectives in one or more separate categories, but connected with common elements.

Next, I propose a three-stage risk management model: risk assessment, risk response and reporting based on international auditing standards, IAS.

Classical economists have taken rationality into account when shaping decision-making practices [21]. Risk identification is the first step in the risk assessment process. The purpose of this model is to identify events that pose a risk as early as possible, thus reducing or eliminating surprises. As a result of risk identification, risk analysts / risk managers may develop a sense of the sources of risk (or opportunities) that will affect the company's projects and operations. Then, they analyses, from a qualitative and quantitative point of view, the impact of risky events, which is the second step in the risk assessment process.

Once the impact of identified events that could present a risk has been analysed, risk analysts, together with managers and actors involved in corporate governance, plan the risk response, developing strategies to address risky events. 
Florin BOGHEAN | Lumen Proceedings 13 | NCOE4.0 2020

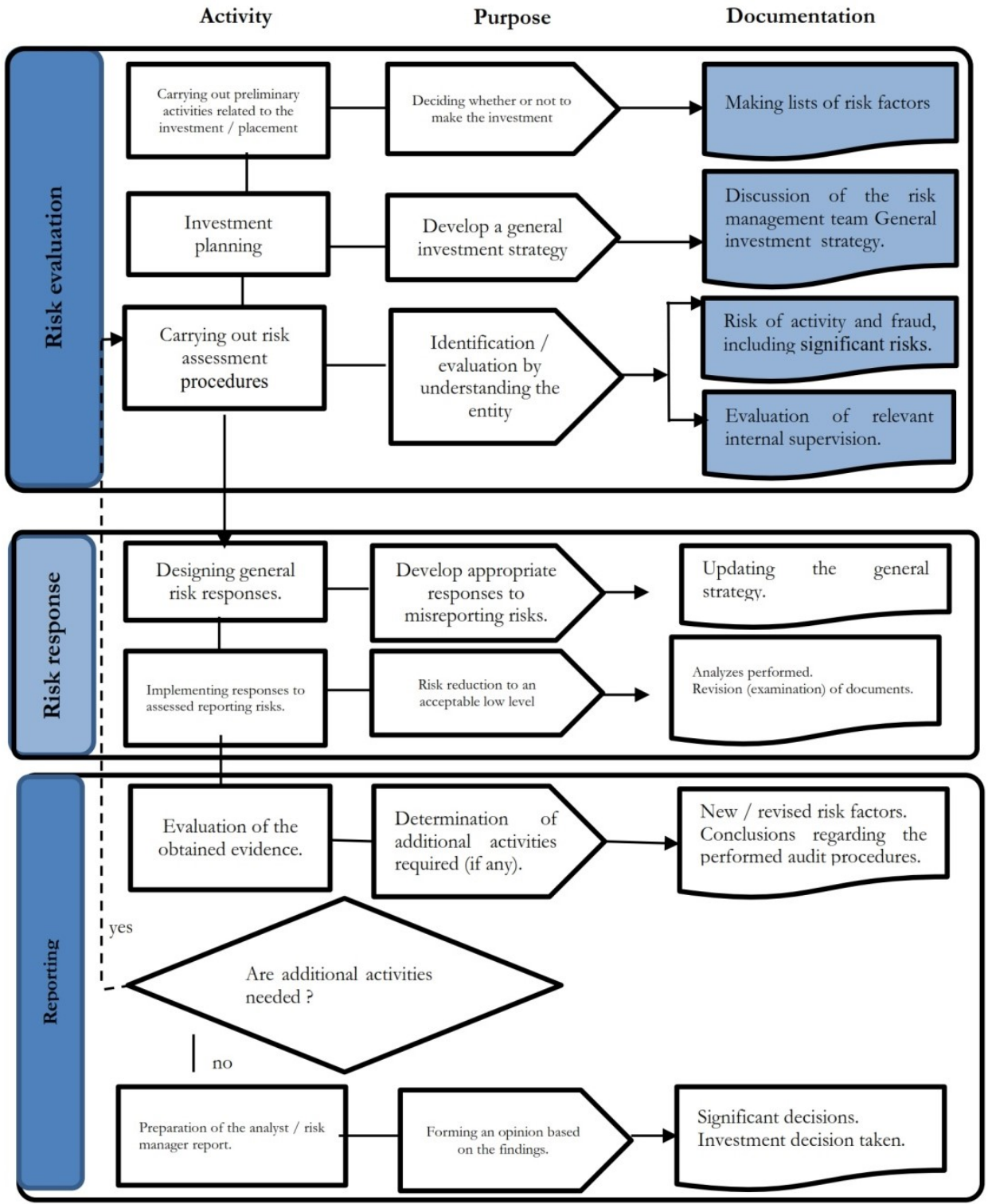

Figure no. 1: Risk management model related to a financial investment Source: author's own processing

During each risk management control cycle, attempts are made to identify the risks. For example, during placement assessments, it is possible to set aside time for issues / situations that have arisen since the last meeting. If no significant risk situations / scenarios are identified, then no 
further action should be taken until the next step. If risky events with a high impact factor have occurred, then their impact is assessed, strategies are developed to deal with them, and strategies are incorporated into decisionmaking processes, the cycle resumes.

\section{Conclusion and proposals}

Making an informed decision, taking into account the significant risks, is essential for management, which can only maximize its likelihood of achieving the proposed objectives. Moreover, the identification of risks allows the entity to take the necessary measures to reduce them and, consequently, to maximize the probability of achieving the proposed objectives. As I said, in reality the risks cannot be completely eliminated, so the entity must reduce them to the maximum level it is willing to accept. It depends on one company to another and may even be different over time for a company.

There are many benefits of incorporating risk management into decision-making processes, including:

- a higher probability of achieving the business objectives;

- more attention paid to the issues that really matter;

- reducing the time lost driving with disputes;

- consolidated reporting of disparate risks at the level of the board of directors

- improving the understanding of key risks and their wider implications;

- improving the decision-making process by integrating risks;

- identifying and sharing information about business risks that are relevant to several functional structures;

- more attention to doing the right things in the right way;

- greater possibility to achieve the company's objectives;

- increased possibility of changing initiatives and achieving the benefits of the projects / projects;

- risk-taking and much more informed decision-making;

- support for innovation;

- lower insurance costs.

In general, an investor, an individual or a company wants to find exactly that business that maximizes its return based on the risk it is willing to take. The surest alternative would be to keep the money in his pocket, but this will not generate any casting; probably the most insecure would be to play them in Loto or gambling. A middle ground would be to invest in either 
stocks or bonds. In the case of shares, dividends are not guaranteed in terms of payment or level, so the risk of losing or receiving less than in the case of an alternative capital investment is higher when it comes to investing in shares than in bonds. An investor with a higher risk appetite will choose the shares, relying on a better return than the bonds.

In addition to all the benefits that an effective risk management system can have, there are certain entities that have the obligation to organize such a system, which is considered an essential part of corporate governance.

\section{References}

[1] Boghean F. Managementul riscului proceselor decizionale in contextul unei guvernante corporative eficiente. Bucuresti: Editura ProUniveristaria; 2019.

[2] Grable J, Roszkowski M, Joo S, O'Neill B, Lytton R. A test of the relationship between self classified financial risk-tolerance and investment risk-taking behaviour, International Journal of Risk Assessment and Management. 2009; 12 (2-4): 396 - 419.

[3] Evans JSBT. Intuition and Reasoning: a Dual-Process Perspective, "Psychological Inquiry"; 2010, No. 21.

[4] Păunescu M. Guvernanța corporativă, managementul riscului și controlul intern, Editura Cecccar, București; 2019.

[5] Heather M, Wegner DM, Gray K. Dimensions of mind perception, Science 2007, 315 (5812): 619.

[6] Lesage C, Wechtler H. An Inductive Typology of Auditing Research, Contemporary Accounting Research; 2010, 29(2).

[7] Raz T, Shenhar A, Dvir D. 2Risk management, project success, and technological uncertainty, R \& D Management 2002, 32 (2): 101-109.

[8] Sheffi Y. The Resilient Enterprise: overcoming vulnerability for competitive advantage. Cambridge, MA: MIT Press; 2005.

[9] Shi Y. Today's Solution and Tomorrow's Problem: the business process outsourcing risk management puzzle, California Management Review; 2007.

[10] Zwikael O, Sadeh A. Planning effort as an effective risk management tool, Journal of Operations Management. 2007, 25 (4) (June): 755-767.

[11] ACCA. Governance, risk and ethics - study text, Kaplan Publishing; 2017.

[12] Zsidisin GA, Smith ME. Managing Supply Risk with Early Supplier Involvement: A Case Study and Research Propositions, The Journal of Supply Chain Management; 2005, 41 (4): 44-57.

[13] Talluri S, Narasimhan R, Nair A. Vendor performance with supply risk: $A$ 
chance-constrained DE $A$ approach, International Journal of Production Economics; 2006, 100 (2) (April): 212-222.

[14] Knemeyer AM, Zinn W, Eroglu C. Proactive planning for catastrophic events in supply chains, Journal of Operations Management; 2009, 27 (2) (April): 141- 153.

[15] Gray JV, Roth AV, Leiblein MJ. Quality risk in offshore manufacturing: Evidence from the pharmaceutical industry, Journal of Operations Management; 2011, 29 (7-8) (November): 737-752.

[16] Zwikael O, Sadeh A. Planning effort as an effective risk management tool, Journal of Operations Management; 2007, 25 (4) (June): 755-767.

[17] Lowenstein R. When Genius Failed: The rise and fall of long-term capital management, Random House; 2000.

[18] Patterson S. The Quants: How a new breed of math whizzes conquered Wall Street and nearly destroyed it, Crown Business; 2011.

[19] Lewis M. The Big Short: Inside the doomsday machine, New York, NY: W. W. Norton \& Company, Inc.; 2010.

[20] Zuckerman, G Greatest Trade Ever: The behind-the-scenes story of how John Paulson defied Wall Street and made financial history, New York, NY: Random House; 2009.

[21] Keeney RL, Raiffa H. Decisions with Multiple Objectives: Preferences and Value Tradeoffs, New York, NY: Wiley; 1976. 